\title{
KORELASI KADAR LEMAK DAN LAKTOSA DENGAN BERAT JENIS SUSU SAPI FRIESIAN HOLSTEIN DI KECAMATAN NGABLAK KABUPATEN MAGELANG
}

\author{
Danes Suhendra*, Widitya Tri Nugraha, Yosephine L. R. E. Nugraheni, Lilis Hartati \\ Program Studi Peternakan, Fakultas Pertanian, Universitas Tidar \\ J1. Kapten Suparman No. 39, Potrobangsan, Kecamatan Magelang Utara 56116 \\ *Email : danes_suhendra@untidar.ac.id
}

\begin{abstract}
ABSTRAK
Berat jenis susu dan kadar lemak digunakan sebagai indikator penerimaan produksi susu segar dari peternak oleh Industri Pengolahan Susu (IPS). Beberapa IPS menentukan harga susu berdasarkan kadar lemak dan laktosa susu. Penelitian ini bertujuan untuk mengkaji korelasi antara kadar lemak, kadar laktosa, dengan berat jenis susu. Materi yang digunakan adalah 90 ekor sapi FH laktasi pada periode laktasi II - III dan bulan laktasi 2 - 3. Analisis yang digunakan adalah regresi korelasi linier sederhana. Hasil menunjukkan bahwa peningkatan kadar lemak dan laktosa susu, menyebabkan peningkatan berat jenis susu masing-masing sebesar 70,8\% dan 68,7\%. Kadar lemak dan laktosa dengan berat jenis susu memiliki nilai korelasi yang nyata $(\mathrm{P}<0,01)$. Keseluruhan perhitungan menunjukkan bahwa ada hubungan antara kadar lemak dan laktosa susu dengan berat jenis susu. Kadar lemak dengan berat jenis susu, dan kadar laktosa dengan berat jenis susu menunjukkan korelasi positif yang sangat kuat. Kesimpulan yang diperoleh bahwa ada hubungan positif antara kadar lemak dan laktosa dengan berat jenis susu. Korelasi antara kadar lemak dan laktosa dengan berat jenis susu adalah semakin tinggi kadar lemak dan laktosa, maka semakin tinggi berat jenis susu.
\end{abstract}

Kata kunci: Sapi FH, kadar lemak, kadar laktosa, berat jenis susu

\section{CORRELATION OF FAT AND LACTOSE CONTENT WITH MILK DENSITY OF FRIESIAN HOLSTEIN COW IN NGABLAK DISTRICT MAGELANG REGENCY}

\begin{abstract}
Milk density and fat content are used as indicators of milk production from dairy farmer by Milk Proccessing Industry (MPI). Some MPI determines the price of milk based on fat and milk lactose content. This research was aimed to study the correlation of fat content, lactose content, and milk density. The material used were 90 of lactation FH cows in the II - III lactation periode and month of lactation are $2-3$. The analysis method used was simple linear correlation regresion. The results showed that during increased milk fat and lactose contents, will increased milk density. Fat and lactose content are significantly correlated with milk density $(\mathrm{P}<0.01)$. The overall calculation shows that there was a relationship between fat content and lactose content to milk density, each 70.8 and $68.7 \%$. Fat content with milk density, and lactose content with milk density showed a strong positive correlations. In conclusion, there was a correlation between fat content and lactose content with milk density. The correlation of fat content and lactose content with milk density were the higher fat and lactose content, higher milk density.
\end{abstract}

Key words: FH cows, fat content, lactose content, milk density

\section{PENDAHULUAN}

Sapi perah Friesian Holstein (FH) merupakan bangsa sapi yang sangat umum dibudidayakan oleh peternak susu di Indonesia. Sapi FH memiliki produksi susu rata-rata $2.000-2.500$ liter per laktasi dengan kadar lemak 3,5 - 3,7\%, sehingga lebih banyak dikembangkan karena produksi susunya yang tinggi (Syarief \& Sumoprastowo, 1990). Bangsa sapi FH mempunyai ciri-ciri antara lain warna bulunya dominan belang hitam putih dan dalam jumlah kecil ada yang berwarna belang merah putih, kepala berukuran relatif panjang, lebar dan lurus dengan tanduk relatif pendek yang mengarah lateral dan melengkung ke depan, serta bertemperamen tenang dan jinak (Siregar, 1993).

Susu adalah cairan putih mengandung nutrien berupa lemak, laktosa, protein, dan beberapa vitamin dan mineral, yang dikeluarkan oleh semua mamalia betina dewasa sebagai makanan untuk anak-anaknya (Guetouache et al., 2014). Susu merupakan makanan dengan nutrisi alami lengkap dan seimbang dengan perbandingan gizi yang sempurna sehingga sangat dibutuhkan oleh manusia. Beberapa komponen mayor penyusun bahan kering susu antara lain lemak, 
karbohidrat, protein, vitamin dan mineral (Prasetya, 2012). Lemak termasuk salah satu penyusun susu yang berperan cukup penting karena mempunyai nilai ekonomi, nilai gizi tinggi, indikator bau, rasa dan lainlain pada susu.

Konsumsi susu segar akan terus terjadi peningkatan seiring dengan adanya peningkatan populasi penduduk, pertumbuhan ekonomi, peningkatan kualitas pendidikan, kesadaran gizi dan perubahan gaya hidup. Kualitas susu dari peternak lokal masih di bawah standar, bahkan di bawah standar yang ditentukan oleh koperasi maupun Industri Pengolahan Susu (IPS) (Anindita \& Soyi, 2017). Salah satu aspek yang digunakan koperasi dan IPS sebagai indikator penerimaan susu segar dari peternak susu lokal adalah berat jenis susu. Masing-masing koperasi susu dan IPS membuat standar berat jenis untuk penerimaan susu yang berbeda-beda. Selain berat jenis, komponen lain yang sering digunakan adalah kadar lemak dan laktosa susu. Beberapa IPS menerapkan pemberian bonus harga bagi peternak yang menyetorkan susu dengan kadar lemak dan laktosa di atas standar IPS. Badan Standarisasi Nasional (2011) mengatur nilai minimum berat jenis susu sapi adalah 1,027 dan kadar lemak minimum $3,00 \%$.

Tujuan penelitian ini adalah untuk mengkaji hubungan antara kadar lemak, kadar laktosa, dengan berat jenis susu. Manfaat dari penelitian ini adalah memberikan informasi kepada peternak susu berupa ilmu pengetahuan mengenai hubungan kadar lemak, laktosa, dan berat jenis susu, sehingga nantinya dapat digunakan sebagai dasar untuk peningkatan kualitas susu. Manfaat bagi IPS adalah, menjadi berat jenis (BJ) susu menjadi indikator kualitas susu yang meliputi kadar lemak, laktosa, dan kasein susu.

\section{MATERI DAN METODE}

Materi yang digunakan dalam penelitian ini adalah 90 ekor sapi perah $\mathrm{FH}$ laktasi pada periode laktasi II - III dan bulan laktasi 2 - 3 dengan frekuensi pemerahan dua kali sehari, pagi dan sore hari. Peralatan yang digunakan yaitu ember/ milk can stainless berskala untuk menampung dan menakar volume susu segar hasil pemerahan, lactoscan untuk mengukur kualitas susu segar hasil pemerahan.

Penelitian ini dimulai dengan survey, yang dilakukan satu bulan sebelum memulai pengamatan dan pengambilan sampel penelitian. Survey dilakukan untuk memilih sapi yang akan digunakan sebagai materi penelitian dengan berdasarkan kartu recording ternak yang dimiliki. Lokasi penelitian yang digunakan adalah Asosiasi Ternak Sapi Perah Tri Argo Mulyo Kecamatan Ngablak Kabupaten Magelang Provinsi Jawa Tengah.

Pemerahan dilakukan secara manual (hand milking) sebanyak dua kali sehari, pagi dan sore hari. Koleksi sampel susu dilakukan secara proporsional, yaitu dicampurkan hasil pemerahan pagi dan sore hari secara proporsional dengan berdasarkan pada persentase volume hasil pemerahan pagi dan sore, kemudian diambil $200 \mathrm{ml}$ sebagai sampel utama. Sampel utama susu kemudian dianalisis menggunakan mesin lactoscan buatan Bulgaria milik koperasi Banyuaji di Kecamatan Getasan Kabupaten Semarang.

Variabel yang diamati adalah berat jenis (BJ), kadar lemak, dan kadar laktosa susu. Data yang diperoleh kemudian dianalisis dengan analisis regresi korelasi linier sederhana menggunakan bantuan program SPSS versi 16.0. Penafsiran besaran koefisien korelasi yang digunakan sesuai petunjuk dari Sugiyono (2006) adalah:
$\checkmark \quad 0,00-0,199$
$\checkmark \quad 0,20-0,399$
$\checkmark \quad 0,40-0,599$
$\checkmark \quad 0,60-0,799$
$\checkmark \quad 0,80-1,000$
$=$ Korelasi sangat rendah
$=$ Korelasi rendah
$=$ Korelasi sedang
$=$ Korelasi tinggi
$=$ Korelasi sangat kuat

\section{HASIL DAN PEMBAHASAN}

Kadar Lemak, Kadar Laktosa, dan Berat Jenis Susu Berdasarkan analisis kualitas susu (kadar lemak, kadar laktosa, dan berat jenis susu) yang telah dilakukan, didapatkan hasil analisis seperti pada Tabel 1 .

Tabel 1. Hasil pengamatan kadar lemak, kadar laktosa, dan berat jenis susu

\begin{tabular}{lccl}
\hline \multicolumn{1}{c}{ Peubah yang Diamati } & Kisaran & Rata-rata & \multicolumn{1}{c}{ Standar } \\
\hline Kadar Lemak Susu (\%) & $2,57-4,34$ & 3,42 & Minimal 3,00* \\
Kadar Laktosa Susu (\%) & $2,96-5,11$ & 3,98 & $4,10^{* *}$ \\
Total Solid (\%) & $9,41-13,59$ & 11,81 & Minimal 10,8* \\
Berat Jenis Susu & $1,018-1,034$ & 1,025 & $1,027-1,030^{*}$ \\
\hline
\end{tabular}

Keterangan :

* Badan Standarisasi Nasional (2011)

** Syafri dkk. (2014)

Hasil penelitian diperoleh rataan kadar lemak susu adalah 3,42\% (Tabel 1). Nilai ini cukup tinggi untuk kadar lemak susu sapi FH. Lemak termasuk salah satu penyusun susu yang berperan cukup penting karena mempunyai nilai ekonomi, nilai gizi tinggi, sebagai indikator bau, rasa dan lain-lain pada susu. Semakin tinggi kadar lemak susu, rasa gurih pada susu semakin terasa. Semakin rendah kadar lemak, susu akan terasa hambar. Badan Standarisasi Nasional (2011) menentukan kadar lemak susu sapi minimal adalah 3,00 
$\%$ dengan kadar protein minimal 2,8 \%. Menurut Zurriyati dkk. (2011), kandungan lemak dan protein dalam susu merupakan komponen terpenting karena dapat mempengaruhi harga susu.

Hasil penelitian diperoleh rataan kadar laktosa susu adalah 3,98 \% (Tabel 1). Nilai ini cukup rendah untuk kadar laktosa susu pada sapi FH. Kadar laktosa hasil penelitian ini lebih rendah dibandingkan hasil penelitian Syafri dkk. (2014) sebesar 4,10 \%. Menurut Christi \& Rohayati (2017), laktosa merupakan gabungan dari glukosa dan galaktosa yang banyak ditemukan pada susu. Laktosa susu memberikan rasa manis pada susu, sehingga semakin tinggi kadar laktosa, rasa susu akan semakin manis. Menurut Suhendra et al. (2015), laktosa susu berasal dari asam propionat hasil fermentasi ruminal serat kasar pakan.

Hasil analisis regresi korelasi antara kadar lemak dengan berat jenis, dan korelasi antara kadar laktosa dengan berat jenis susu sapi FH dalam penelitian ini seperti tertera pada Tabel 2.

Tabel 2. Persamaan regresi, koefisien korelasi (r), koefisien determinasi $\left(\mathrm{R}^{2}\right)$ antara kadar lemak (KL) dengan berat jenis susu (BJ), dan kadar laktosa (KL) dengan berat jenis (BJ) susu sapi FH

\begin{tabular}{lccc}
\hline \hline \multicolumn{1}{c}{ Korelasi antar Variabel } & Persamaan regresi & $\begin{array}{c}\text { Koefisien } \\
\text { Korelasi (r) }\end{array}$ & $\begin{array}{c}\text { Koefisien } \\
\text { Determinasi }\left(\mathrm{R}^{2}\right)\end{array}$ \\
\hline Kadar lemak (KL) dengan berat jenis (BJ) & $\mathrm{BJ}=-101,79+102,867 \mathrm{KL}$ & 0,84 & 0,708 \\
Kadar laktosa (KT) dengan berat jenis (BJ) & $\mathrm{BJ}=-491+123,57 \mathrm{KT}$ & 0,83 & 0,687 \\
\hline
\end{tabular}

\section{Korelasi Kadar Lemak dengan Berat Jenis Susu}

Berdasarkan data pada Tabel 2., ditunjukkan bahwa persamaan regresi antara kadar lemak (KL) dengan berat jenis (BJ) susu sapi FH adalah BJ = $101,79+102,867$ KL. Nilai regresi ini menunjukkan adanya hubungan positif antara kadar lemak dengan berat jenis. Semakin tinggi kadar lemak, maka akan semakin menaikkan nilai berat jenis susu sapi FH. Koefisien korelasi (r) sebesar 0,84 yang menandakan bahwa hubungan positif antara kadar lemak dengan berat jenis susu adalah sangat kuat. Hal ini sesuai dengan pendapat dari Sugiyono (2006), yang menyatakan bahwa nilai koefisian korelasi (r) sebesar $0,80-1,000$ memiliki korelasi sangat kuat. Nilai koefisien determinasi $\left(\mathrm{R}^{2}\right)$ sebesar 0,708, artinya peningkatan pada nilai-nilai kadar lemak akan berpengaruh sebesar 70,8 \% terhadap peningkatan nilainilai berat jenis susu.

Kadar lemak susu rata-rata sebesar 3,42\% dan meningkatkan kadar total solid sebesar $11,81 \%$ (Tabel 1.), sehingga meningkatkan berat jenis susu. Kadar lemak susu tersusun dari kumpulan asam lemak jenuh dan tidak jenuh. Asam lemak merupakan salah satu komponen utama penyusun susu selain kasein dan laktosa susu. Peningkatan kadar lemak susu mengakibatkan peningkatan berat jenis susu, sebab asam lemak merupakan salah satu komponen penyusun total solid. Suhendra dkk. (2017) menyatakan bahwa lemak susu tersusun dari asam lemak jenuh dan tidak jenuh. Asam lemak jenuh penyusun lemak susu antara lain asam palmitat (C16:0) dan asam stearat (C18:0). Asam lemak tidak jenuh penyusun lemak susu antara lain asam oleat (C18:1), asam linoleat (C18:2), dan asam linolenat (C18:3). Badan Standarisasi Nasional (2011) menyatakan bahwa kadar lemak minimal pada susu sapi adalah 3,00\%. Ditegaskan oleh Suhendra et al. (2017), kadar lemak dalam susu berada pada kisaran 3,28 - 3,51\%. Saputra (2018) menyatakan bahwa lemak, protein, dan laktosa merupakan komponen utama penyusun total solid susu. Vidiyanto dkk. (2015) menyatakan bahwa nilai total solid mempengaruhi nilai berat jenis susu.

\section{Korelasi Kadar Laktosa dengan Berat Jenis Susu}

Berdasarkan data pada Tabel 2., ditunjukkan bahwa persamaan regresi antara kadar laktosa (KT) dengan berat jenis $(\mathrm{BJ})$ adalah $\mathrm{BJ}=-491+123,57 \mathrm{KT}$. Nilai regresi ini menunjukkan adanya hubungan positif antara kadar laktosa dengan berat jenis susu sapi FH. Semakin tinggi kadar laktosa, maka akan semakin meningkatkan nilai berat jenis susu. Koefisien korelasi (r) sebesar 0,83 yang menandakan bahwa hubungan positif antara kadar laktosa dengan berat jenis susu adalah sangat kuat. Hal ini sesuai dengan pendapat dari Sugiyono (2006), yang menyatakan bahwa nilai koefisian korelasi (r) sebesar 0,80-1,000 memiliki korelasi sangat kuat. Nilai koefisien determinasi $\left(\mathrm{R}^{2}\right)$ sebesar 0,687, artinya peningkatan nilai-nilai kadar laktosa akan berpengaruh sebesar 68,7 \% terhadap peningkatan nilai berat jenis susu sapi $\mathrm{FH}$.

Kadar laktosa susu tersusun dari kondensasi antara galaktosa dan glukosa dalam darah. Galaktosa susu berasal dari penggabungan molekul glukosa dengan Uridine Diphospat (UDP), sedangkan glukosa darah bersumber dari asam propionat dalam rumen. Laktosa dalam sel epitel ambing mengakibatkan perbedaan tekanan osmosis pada sel epitel dan pembuluh kapiler ambing. Perbedaan tekanan osmosis ini menyebabkan sel epitel ambing menarik air dari pembuluh kapiler ambing untuk menyeimbangkan tekanan osmosis. Hal ini menyebabkan kadar air pada susu menjadi meningkat, sehingga akan meningkatkan jumlah air yang menyebabkan peningkatan berat jenis susu. Utari et al. (2012) menyatakan bahwa glukosa merupakan komponen utama dalam pembentukan laktosa susu. Konsumsi Bahan Ekstrak Tanpa Nitrogen (BETN) yang tinggi meningkatkan suplai glukosa dalam darah. Glukosa darah juga dapat berasal dari proses glukoneogenesis asam amino di dalam organ hati. Vidiyanto dkk. (2015) menegaskan bahwa laktosa 
dan air menjadi komponen utama yang mempengaruhi produksi susu. Sekresi laktosa pada lumen ambing menyebabkan perbedaan tekanan osmosis. Hal ini menyebabkan aliran darah menuju sel epitel ambing meningkat, sehingga mengakibatkan air dan garam mineral disekresikan pada lumen ambing untuk menyeimbangkan tekanan osmosis. Semakin tinggi bahan padat pada susu, maka akan semakin tinggi berat jenis susu. Saputra (2018) menyatakan bahwa laktosa bersama kasein dan lemak susu merupakan zat utama penyusun total solid pada susu.

\section{SIMPULAN}

Berdasarkan hasil dan pembahasan di atas, dapat disimpulkan bahwa :

1. Peningkatan kadar lemak dan laktosa susu akan meningkatkan nilai berat jenis susu. Semakin tinggi kadar lemak susu, semakin tinggi nilai berat jenis susu. Semakin tinggi kadar laktosa susu, semakin tinggi nilai berat jenis susu.

2. Kadar lemak susu sapi FH pada Asosiasi Ternak Perah Tri Argo Mulyo sudah memenuhi Standar Nasional Indonesia (SNI). Kadar laktosa dan berat jenis susu sapi FH pada Asosiasi Ternak Perah Tri Argo Mulyo belum memenuhi Syandar Nasional Indonesia (SNI).

\section{DAFTAR PUSTAKA}

Anindita, N. S., \& D. S. Soyi. 2017. Studi Kasus: Pengawasan Kualitas Pangan Hewani Melalui Pengujian Kualitas Susu Sapi yang Beredar Di Kota Yogyakarta. Jurnal Peternakan Indonesia. 19(2): $96-105$.

Badan Standarisasi Nasional. 2011. Standar Nasional Indonesia: Susu Segar Bagian-1: Sapi. Jakarta: Badan Standarisasi Nasional.

Christi, R. F., \& T. Rohayati. 2017. Kadar Protein, Laktosa, dan Bahan Kering Tanpa Lemak Susu Kambing Peranakan Ettawa yang Diberi Konsentrat Terfermentasi. Jurnal Ilmu Peternakan (JANHUS). 1(2): 19-27.

Guetouache, M., G. Bettache, \& M. Samir. 2014. Composition and Nutritional Value of Raw Milk-Review. Issues in Biological Sciences and Pharmaceutical Research. 2(10): 115 - 122.

Prasetya, H. 2012. Beternak Sapi Perah. Yogyakarta: Pustaka Baru Press.
Saputra, F.T. 2018. Evaluation of The Total Solid Fresh Milk of Tawang Argo Farmers Based On Indonesian National Standards. Journal of Tropical Livestock. 19(1): 22-26.

Siregar, S. B. 1993. Sapi Perah, Jenis, Teknik Pemeliharaan dan Analisis Usaha. Jakarta: Penebar Swadaya.

Sugiyono. 2006. Metode Penelitian Kuantitatif Kualitatif dan $R \& D$. Bandung: Alfabeta.

Suhendra, D., G. T. Anggiati, S. Sarah, A. F. Nasrullah, A. Thimoty, \& D. W. C. Utama. 2015. Tampilan Kualitas Susu Sapi Perah Akibat Imbangan Konsentrat dan Hijauan yang Berbeda. Jurnal Ilmu Ilmu Peternakan. 25(1): 42-46.

Suhendra, D., Sudjatmogo, \& Widiyanto. 2017. Pengimbuhan Minyak Jagung Terproteksi dengan Berbagai Level Protein Ransum Sapi Friesian Holstein Meningkatkan Kadar Asam Lemak Tidak Jenuh Susu. Jurnal Veteriner. 19(1): 100-108.

Syafri, A., D. W. Harjanti, \& S. A. B. Santoso. 2014. Hubungan Antara Konsumsi Protein Pakan dengan Produksi, Kandungan Protein dan Laktosa Susu Sapi Perah Di Kota Salatiga. Animal Agriculture Journal. 3(3): 450-456.

Syarief, M. Z., \& C. D. A. Sumoprastowo. 1990. Ternak Perah. Jakarta: CV. Yasaguna.

Utari, F. D., B. W. H. E. Prasetyono, \& A. Muktiani. 2012. Kualitas Susu Kambing Perah Peranakan Ettawa yang Diberi Suplementasi Protein Terproteksi Dalam Wafer Pakan Komplit Berbasis Limbah Agroindustri. Animal Agriculture Journal. 1(1): 427-441.

Vidiyanto, T., Sudjatmogo, \& S. M. Sayuthi. 2015. Tampilan Produksi, Berat Jenis, Kandungan Laktosa dan Air Pada Susu Sapi Perah Akibat Interval Pemerahan yang Berbeda. Animal Agriculture Journal. 4(2): 200-203.

Zurriyati, Y., R. R. Noor, \& R. R. A. Maheswari. 2011. Analisis Molekuler Genotipe Kappa (k-Kasein) dan Komposisi Susu Kambing Peranakan Etawah, Saanen dan Persilangannya. Jurnal Ilmu Ternak dan Veteriner. 16(1): 61-70. 